\title{
Double-stranded RNA adenosine deaminase ADAR1 enhances both T cell susceptibility to human T-cell leukemia virus type 1 and 2 and viral replication
}

\author{
Anne Cachat ${ }^{1}$, Sébastien A Chevalier ${ }^{1}$, Sandrine Alais ${ }^{1}$, Adrien Boniface ${ }^{1}$, Nga Ling Ko ${ }^{2}$, Antoine Gessain²,
} Hélène Dutartre ${ }^{1}$, Renaud Mahieux ${ }^{1 *}$

From 16th International Conference on Human Retroviruses: HTLV and Related Viruses Montreal, Canada. 26-30 June 2013

Type I interferons represent the first line of defense against pathogens. This family of cytokines activates the expression of antiviral proteins, such as the protein kinase R (PKR), an inhibitor of viral mRNA translation, and the double-stranded RNA adenosine deaminase ADAR1. ADAR1 has the ability to convert adenosine (A) into guanosine $(\mathrm{G})$, thereby introducing mutations in the viral genome during its replication. A to G editing was previously reported in cells expressing HTLV-2 or STLV-3 viruses but not investigating in HTLV-1 expressing cells (Ko et al. J. Gen Virol. 2013). Consequently we investigated whether ADAR1 expression was associated or not with an antiviral effect in the course of HTLV-1 and HTLV-2 infections. We first show that ADAR1 expression is increased in ATL patient peripheral blood mononuclear cells, in HTLV-1 and HTLV-2 transformed cell lines as well as in activated primary peripheral blood lymphocytes. Strikingly, in cells transfected with HTLV-1 and HTLV-2 molecular clones, ADAR1 over-expression enhances viral replication and viral egress through PKR functional inhibition, as demonstrated by western-blot analyses, luciferase assays, ELISA and infection experiments. We also demonstrate that this effect is independent of ADAR catalytic activity. In addition, ADAR1 expression enhances the susceptibility of a non-infected T cell line to HTLV-1 and HTLV-2

\footnotetext{
* Correspondence: renaud.mahieux@ens-lyon.fr

'Oncogenèse Rétrovirale, Equipe labellisée Ligue nationale contre le cancer, CIRI, INSERM U1111-CNRS UMR5308, Université Lyon 1, Ecole Normale Supérieure, LabEx ECOFECT - Eco-evolutionary dynamics of infectious diseases, Lyon, Cedex 07, France

Full list of author information is available at the end of the article
}

infection. Altogether, our results demonstrate that an interferon-induced protein exerts a proviral role in the context of HTLV infection by enhancing cells susceptibility to infection and increasing viral replication.

\section{Authors' details}

'Oncogenèse Rétrovirale, Equipe labellisée Ligue nationale contre le cancer, CIRI, INSERM U1111-CNRS UMR5308, Université Lyon 1, Ecole Normale Supérieure, LabEx ECOFECT - Eco-evolutionary dynamics of infectious diseases, Lyon, Cedex 07, France. ${ }^{2}$ Unité d'Epidémiologie et Physiopathologie des Virus Oncogènes, CNRS URA 3015, Institut Pasteur, Paris, Cedex 15, France.

Published: 7 January 2014

doi:10.1186/1742-4690-11-S1-049

Cite this article as: Cachat et al: Double-stranded RNA adenosine deaminase ADAR1 enhances both T cell susceptibility to human T-cell leukemia virus type 1 and 2 and viral replication. Retrovirology 201411 (Suppl 1):049.

Submit your next manuscript to BioMed Central and take full advantage of:

- Convenient online submission

- Thorough peer review

- No space constraints or color figure charges

- Immediate publication on acceptance

- Inclusion in PubMed, CAS, Scopus and Google Scholar

- Research which is freely available for redistribution

Submit your manuscript at www.biomedcentral.com/submit
() Biomed Central 